\title{
The Dilemma of Partnership in the Perspective of Competition Law
}

\author{
Mohammad Reza ${ }^{1}$, M. Hawin ${ }^{2}$, Ningrum Sirait ${ }^{3}$
}

\author{
${ }^{1}$ Universitas Gadjah Mada \\ ${ }^{2}$ Universitas Gadjah Mada \\ ${ }^{3}$ Universitas Sumatera Utara \\ Email: mohammad.reza@mail.ugm.ac.id
}

\begin{abstract}
The welfare of all citizens is the goal of every nation. The Indonesian Government adopted various economic policies to archive it. One of the causes of the financial crisis in Indonesia is unfair business competition, among others nepotism and collusion between the authorities and businesses, thereby shattering the economic structure of Indonesia. Law N.5/1999 on Prohibition of Monopolistic Practices and Unfair Business Competition become tools to abolish nepotism and collusion in business. Competition is the best approach to restore the economy because it will trigger innovation and efficiency to benefit producers and consumers. The fair and open business competition will limit and erode nepotistic and collusive behavior. However, the Indonesian business culture is not oriented to free competition. Article 33 of the Indonesian Constitution contains the philosophy of the Indonesian economy builds on a joint effort of the principle of kinship. This philosophy places partnership as a feature of the Indonesian economy, and Law N.20/2008 on Micro, Small, and Medium Enterprises regulates further. Arduous for Indonesian culture to accept the competition concept since the "gotong royong" is the main principle in economics. Competition and partnerships became a dilemma when vis-a-vis. This research will analyze the crossing path of competition and partnership to find the right approach to harmonize between competition and partnership and as an input for KPPU as an institution that has the mandate to oversee the business competition and supervise partnership.
\end{abstract}

Keywords: partnership, MSME, competition.

\section{INTRODUCTION}

The people's welfare is the aim of every country. However, each country has its challenges in economic and political choices to achieve its goals. The background of the natives, the ideology of the nation's founders, natural and geographical conditions consider how to achieve this prosperity. Discussion on how the State seeks its aim with fair, secure, democratic, and economically prosperous regardless of the implementation of the economic system [1]. The choice depends on the constitution and the State's national interest from the various existing economic systems.

The culture of Indonesian society is family-oriented, characterized by harmony, togetherness, and mutual help. Indonesian culture is not easy to accept competition. Indonesian considers competition a selfish individualist concept, contrary to the idea of community in the family. This family concept is the basis of the nation's philosophy as contained in art.33 par. (1) of the 1945 Indonesian Constitution, stating that "the establishment of the economy shall be a joint enterprise under the principles of kinship." Developing every citizen's potential, initiative, and creative power within limits does not harm the public interest. With this philosophical view, the pattern of working together can be a feature of the Indonesian economy that prioritizes a culture of joint business.

Post the New-Order regime, Indonesia made a transition from economic liberalization to a market economy and carried out many deregulations in the process. Indonesia took this choice even though the NewOrder has been achieving many developments seen through high economic growth, Indonesia still has many unresolved problems in economic development. In addition to economic globalization, which has become the dynamics of the modern economy, which requires business actors to adapt to it, the implementation of the 
national economy tends to show a monopolistic pattern. Businesses intimate to the elite power gain excessive facilities impacted to social inequality. The emergence of conglomerates and a small group of niche businesses with no strong entrepreneurial passion is one factor that compels economic resilience to turn fragile and unable to compete. [2] As a result, Indonesia became one of the worst-hit countries compared to other ASEAN countries when the financial crisis hit. [3]

The policymakers willed the businesses can grow and develop healthily and correctly. Therefore, they drive at avoiding the concentration of economic power on specific individuals or groups, among others, monopoly practices and unfair business competition that are detrimental to society that is contrary to social justice ideals. Furthermore, it ultimately creates a healthy business competition climate.

Indonesia now has been 20 years of implementing the competition law. Competition Law is an essential element as a "code of conduct" for business actors to compete fairly in the market under the rules of law. The State is interested in competition policies to maintain the continuity of the process of freedom of competition aligned with the freedom of trade, freedom of choice, and access to the market [4]. It is not easy for Indonesia to change from a government-controlled economic model to a competitive market and reduce externalities [5]. However, this transition to transform is essential because it redefines the State's role in the economy [6].

The Indonesian economy orientation is towards togetherness, the people's economy, harmony, and a foster-father system to support micro, small, and medium enterprises (MSEMEs). The Indonesian Government has a solid commitment to protecting MSMEs, among others, through partnerships [7]. Competition policymakers will be at a crossroads and face a dilemma, whether the policies taken will lead to efforts to prepare business actors to encounter economic globalization or stand with micro, small and medium enterprises. If the policymakers want to prepare the businesses for global competitiveness, then one of the primary keys is efficiency. Usually, the small will be weaker and lose in the competition.

On the other hand, if Indonesia intends to protect MSMEs, the previous phenomenon may reappear. Protection raises several businesses with a strong engagement with elite power but without solid entrepreneurial passion. Therefore, the question raised in this paper is how to harmonize the concept of partnership in competition law?

\section{WELFARE STATE AND ECONOMIC SYSTEM TO ACHIEVE PROSPERITY}

All countries want political and economic stability that will lead to realizing social welfare for all their people. However, each country has its way of looking at the meaning and how to achieve this prosperity. Therefore, from the various existing economic systems, each country will choose and implement an economic system that is considered appropriate based on the nation's philosophy and national interests.

The concept of a welfare state was started around the $18^{\text {th }}$ century when Bentham [8] promoted the idea that the Government had a responsibility to guarantee "the greatest happiness of the greatest number." He uses the term utility to describe the concept of happiness or wellbeing. Based on the principle he developed, anything that can escalate to extra happiness is good. But, something that causes pain is terrible. Another figure who helped popularize the welfare state system was Beveridge [9], who proposed a comprehensive social insurance system that he saw as protecting people from "cradle to grave."

Pure capitalism, in the beginning, was considered quite attractive because it was convincing to be able to provide welfare to the community. In "The Wealth of Nations," Smith [10] describes that the price system will work and how a free and competitive economy will function without interference from the Government through the allocation of resources in an efficient manner. Smith introduced the term "invisible hand," which will make the production goals, the needs of the community per social goals, to avoid unwanted effects in the allocation of resource use. Smith [11] suggests that competition is natural as checks and balances control individual desires to exploit the market. Therefore, competition is assumed to be a good solution in the economy. The main basic principle for market economy excellence is the will to pursue the most significant profit and happiness for every individual through competition. He also emphasized that government intervention against the market is not needed if market efficiency runs maximum.

Economic efficiency is a description that describes efforts to achieve maximum welfare goals or actions to get maximum value from limited community resources and is used to measure economic welfare [12]. Therefore, although the competition process results in some people losing in competition and becoming social dependents in the economy, competition is considered the most appropriate mechanism to achieve prosperity through the maximum allocation of resources. However, this economic system model raises concerns that the intended welfare will be enjoyed only by a group that has capital. And the victims are none other than the workers. Fear of a gap between rich and poor inspired Marx to write Das Kapital [13]. Marx's theory was proven wrong with the fall of the Soviet Union with its purely socialist system. But that does not mean that capitalism remains the primary choice. In 1936, the capitalist system experienced a global depression, making workers, investors, and businessmen miserable [14]. 
The reality of this dilemma gave rise to List's [15] view on the not-pure capitalist system, to wit implementing a capitalist economy but with state regulation, referred to as State Capitalism or National Capitalism. Whether realize it or not, countries in Southeast Asia have implemented this system, which Yoshihara calls Ersatz Capitalism [16]. The main characteristic of Ersatz Capitalism is the existence of compromises and excessive government economic intervention, which is detrimental to the free market system, and the practice of rent-seeking, which is rapidly developing into socio-political behavior in these countries [17].

Wagner later refined the List version of the state capitalism model in the form of the Welfare State. This capitalist system regulates the allocation of government funds to redistribute national wealth. Keynes later refined this model by calling it a mixed economy system, contrary to the system approach of socialism, either pure socialism or mixed socialism with a market system. The People's Republic of China, Yugoslavia impalements mixed socialist systems and several African countries. Keynes showed errors in the capitalist system itself and corrected and perfected it, and subsequently, this system hit the world economy. Although Keynes's correction has uttered to a new paradigm for Smith's theory, it is not easy to change the economic view that is still loyal to the classical and neoclassical ideas, which still believe that the market will work by itself as the laissez-faire theory [18].

Mubyarto [19] critiqued that contemporary capitalism is becoming more accommodative. The most critical change is recognizing the importance of government and state intervention in certain circumstances, even though the country adheres to a liberal economy. Likewise, Kadir [20] emphasized that the actual definition of liberalism or market freedom is more of a myth because the State is the leading actor in regulating the traffic mechanism and the efficient allocation of goods and resources with an essential benchmark on market prices. The State does not exist vis$a$-vis the market but repeatedly negotiates with the capitalist class.

The process of competitive liberalization encourages many countries to compete aggressively, regardless of their philosophy. The last decade shows that many countries in Asia have adopted an economic system that tends to change towards a more liberal direction by adopting a market economy system. Even various countries accustomed to the tradition of protectionism, such as China, implements competitive liberalization [21].

Conditions that occur in Indonesia are not much different from practices that occur in other countries. Although still referring to Pancasila, Indonesia is also experiencing changes in the economic system. The Old-
Order era, the New-Order era, and the Reform era have their perspectives in understanding the economy based on Pancasila. Transformation is not illegal. In terms of legal changes, there are 2 (two) kinds of laws, namely laws that tend to be changeable and laws that tend to be conservative. For example, family law or intellectual property laws are customary laws and are rarely changed. On the other hand, many business laws, state administration, and state administration tend to change according to the wishes and developments in society [22].

Before the crisis, the Indonesian economy showed rapid development and even became a lucrative market for other producing countries [23]. Praise the success of the Indonesian economy, Hill's [24] writings: "The Indonesia of the mid-1990s is almost unrecognizable compared to that of the mid-1960s. From the despair of the earlier period, the new regime could engineer an amazingly rapid recovery, as manifested in sharply declining inflation and rising growth. Indeed, a little more than a decade on, Indonesia was being hailed as one of Asia's success stories. Economists cite Indonesia from 1966 to 1968 as one of the swiftest and effective instances of inflation control in the 20th century. the fruit by the late 1980s, among the select group of developing countries, Indonesia classified to become newlyindustrialized economies following the successful path of Asia's outward-looking industrial economies."

When Indonesia became one of the country's worst hits by the economic crisis in the Asian region, it proved that the highly praised Indonesian economy was nothing more than a mirage [25]. Therefore, policymakers should ponder what has happened to the Indonesian economy. What should improve the Indonesian economic system? Which economic system should choose to make Indonesia grapple with the current era of liberal competition? After Indonesia chooses an economic system, what are the mitigation steps that Indonesia must take to be strong in encountering economic shocks? And there are many other thoughts. This mitigation is essential since Indonesia is an emerging market state with a high economic growth rate taken into account on the global stage. But in recent years, it has become clear that the structure of Indonesia's economy is fragile. As a result, in early 2013, the term Fragile Five emerged, named from the five countries with exchange rates most vulnerable to shocks due to capital flight. The five countries are Brazil, Indonesia, India, South Africa, and Turkey [26].

The history of the development of thought about science and economic concepts in Indonesia is fascinating to study until now. It seems like it is endless and even continues to grow. It is recorded in history that Indonesian economists and politicians discussed and conducted studies on the right name for Indonesia's economic system for a long time. Movement leaders like Hatta repeatedly wrote about the dangers that threaten the 
people's economy and how they must unite or unite themselves. [27]

The economic concept that Indonesia must embrace has become a serious debate among Indonesian economists, primarily when it is associated with three issues. First, the choice of economic ideology by the Indonesian Government to design future economic development; second, the economic foundation of Indonesia after the independence of the Republic of Indonesia; and third, the direction and vision of Indonesia's economic growth. The concept of the Indonesian economy in the era of President Soekarno's leadership referred to independence, sovereignty, and self-sufficiency. These three keywords are often known as the basic concept of "Tri Sakti Pancasila." The conceptual basis of the Tri Sakti Pancasila emphasizes that it is sovereign in the political field, independent in the economic area, and has a personality in the cultural field. However, in practice, there have been various changes and ideological orientations. The period 19451959 adopted a liberal economic system. However, the liberal financial plan foundered in the middle of the road because it caused high prices and low currency values. The guided economy in 1959-1965 replaced the liberal economic system. This system also generates a state budget deficit, foreign aid stops, and the income per capita of the population declines so that the country almost goes bankrupt [28].

Currently, there are two taught economics adopted, capitalist economics and socialist economics. But in practice, almost all over the world is a mixed economic system. The difference is in the degree of inclination. If the State is heavy, marked by the State's prominent role, it tends to a socialist economy. On the other hand, if it is more private heavy, characterized by the State's minimal role, it tends towards/or is called a capitalist or freemarket economy [29]. Although they look different, they all have the same goal, namely prosperity. Thus, there is enormous attention to the concept of a welfare state because it is considered the most appropriate answer to state involvement in advancing people's welfare. This confidence reinforces by the emergence of empirical facts regarding market failure and state failure in improving people's securities.

Constructing a welfare state has become an obsession for many new countries, especially Asia, which became independent after World War II. South Korea, Taiwan, and Singapore have been successful in establishing their welfare states. Likewise with the Republic of Indonesia. With the ideology of Pancasila, the founding fathers of the nation wanted prosperity for all the people. Atmoredjo [30] describes welfare as a comfortable and happy home for the life of the Indonesian people. The Ideology of Pancasila concretized in the 1945 Indonesian Constitution designed Indonesia as a Welfare State. Paragraph fourth of the Preamble of the 1945 Indonesian
Constitution mentions "...to establish a Government of the State of Indonesia to protects the entire Indonesian nation and the entire homeland of Indonesia. To promote public welfare, educate the nation's life, and participate in carrying out world order based on independence, eternal peace, and social justice..."

\section{INDONESIAN ECONOMIC SYSTEM IN COMPETITION PERSPECTIVE}

Competition creates economic efficiency, market entry opportunities, reduction of government regulations and market concentration, prioritizing consumers and people's welfare. Competition policy and the competition law are the determining factors in achieving welfare goals [31]. Indonesia recognizes a culture of harmony, togetherness, and competition, which is not parallel to these values. Competition is interpreted as an individualistic act and only orientates to its interests. Justify all means only to achieve the maximum profit. Truthfully fair competition shows formidable business actors through efficiency, innovation, and the best strategies.

Bork [32] said that competition provides society with the maximum output that can be achieved at any given time with the resources at its command. Under a competitive regime, productive resources are combined and separated, shuffled, and reshuffled in search of greater profits through greater efficiency. As a result, each abundant resource moves to that employment, where the value of its marginal product, and hence the return paid, is utmost. Thus, the output can maximize since there is no possible rearrangement of resources that could increase the total output value to consumers. Therefore, competition is desirable because it assists in achieving a prosperous society and permits individual consumers to determine by their actions what goods and services, they want most.

Competition is an attempt to gain profit through market mechanisms [33]. Competition occurs in various forms, for example, price, quantity, services, or a combination of multiple factors that consumers will assess [34]. Economists argue that competition has an impact on prices determined through market mechanisms. The use of resources becomes efficient to reduce production costs. As a result, the competition will produce varied products at competitive prices and benefit both producers and consumers [35].

Competition defines as a situation in the market in which firms or sellers independently strive for buyers' patronage to achieve a particular business objective, e.g., profits, sales, and market share [36]. In this context, competition often equalizes rivalry. Competitive rivalry between firms can occur when there are two firms or many. This rivalry may occur in forms of price, quality, service, combinations, and other customer value factors 
[37]. Competition is an essential process by which firms push to be more efficient and offer better choices of products and services at lower prices. Thus, it increases consumer welfare and allocative efficiency. Moreover, it includes the concept of dynamic efficiency, that engage businesses for innovation and foster technological change and progress.

Globalization is not an inevitable destiny but a human design to integrate countries' economies in a mechanism. Globalization is a technological, economic, social, political, and cultural phenomenon that begins with trade in goods, services, and factors of production later followed by economic integration between countries. Economic globalization makes countries borderless and opens the door to the capitalist system [38]. Numerous countries then entered into free trade agreements, such as APEC, AFTA, and WTO. Another form of entry into the flow of economic globalization and free markets is investment liberalization. Liberalization is carried out by reducing tariff and non-tariff barriers and supporting competitive market competition, which results in consumer welfare.

The Ministerial Meeting to the APEC Summit in 2004 [39] stated that regardless of the economic system adopted by a country, every country is moving in the same direction, namely global competition and free trade liberalization. Globalization that surges the world defines as the equivalent of free trade. However, free trade is often interpreting as free competition, which has a negative connotation: self-interest. Competing refers to an individualistic and unilateral interest-oriented action by doing various ways to achieve the maximum benefit.

Economic activities that have transcended national boundaries demand regulations to enforce the rule of law and provide equal protection for every business to create a fair business environment. The culture, behavior, and values that live in the society of a country influence the choice of policies and administrative decisions. In countries with individualistic cultures are easier to adopt competition and free competition policies. In contrast, countries with collaborative cultures prefer trade policies that are centralized in nature and allow significant government intervention in the economy [40].

Free competition is adhered to in the competition law system in the United States [41]. Indonesia often defines a free-market economy as free-flight liberalism. However, many empirical facts show that the world's population is tired, fed up, and hates all forms of free competition, because it will only give birth to a "stressful society" or a "restless society." Therefore, many parties have spoken out loud about the need to live in peace, live in harmony, live comfortably for the sake of realizing "peace-loving nations." [42]. This condition manifests in the European Union, which drafted its competition law to ensure fair competition, encourage innovation, homogenize standards, and protect small businesses [43].
The development of the ASEAN single market also resembles the European Union. Research by Setianingrum and Hawin [44] suggests the possibility of adopting the European Union supranationalism system for competition law cases across ASEAN member countries. However, each country has sovereignty to apply its national competition law, because business competition's characteristics, and legal nature and provision vary between ASEAN member countries.

Competition is natural. It exists in the souls of individuals, nonetheless for Indonesia, competition has become a legal science that is growing after the enactment of Law 5/1999. Competition in Indonesia certainly cannot be equated with competition adopted in other countries. Pancasila in Indonesia is the basis of competition philosophy and paradigm. As the basis of philosophy, Pancasila is non-negotiable. Pancasila leads us to crystallize the mindset and attitude, life and life behavior, and state administration.

The competition law concept in Indonesia cannot separate from the Pancasila paradigm. Competition in Indonesia stands based on economic democracy by taking into account the harmony between the interests of businesses and the public benefits. Indonesia chooses the direction of the nation's political economy favoring MSMEs because they are the main pillars of the national economy. Therefore, MSMEs must obtain the primary opportunities, support, protection, and development as widely as possible without disregarding the prominent role of large businesses and state-owned enterprises.

The 1945 Indonesian Constitution mandated the principles of a Pancasila economy, including humanitarianism, economic nationalism, economic democracy, and justice. Indonesian populist economics known as Pancasila Economy, is an economic system that aims to reflect the five principles of Pancasila. In essence, the Pancasila economy is a system that tries to avoid pendulum-like swings from far right to far left and vice-versa. In simple expressions, The Pancasila Economy describes as a market economic system with government control or a controlled market economy. The Pancasila economy can be considered an example of a mixed economy or a third-way economic system. It is the opposite of a neo-classical approach that promotes individualism and free markets. The Pancasila Economy also adapts the values of Indonesian society, including religious values, culture, customs, and norms. The Pancasila economy portrays the dimensions of justice and equality. on the other hands

Every society has and known competition values. According to the Chinese, its 'Harmonious World' is based on lasting peace and common prosperity and consists of five elements: a 'win-win' strategy; peaceful development; the respect for diversity; cooperation and coordination; and peaceful coexistence. Its essence can be summarised as follows: a) differences can be resolved 
through dialogue; b) tension can be defused through consultation; c) common development can be reached through economic cooperation; and d) cultures can be enriched through exchanges. [45] There are points of similarity between Indonesia and China in emphasis on the principle of cooperation. The approach to the aspect of competition with cooperation begins with an awareness of the competition's weaknesses. Nalebuff and Brandenburger [46] emphasize the importance of competition and cooperation. The competition reflected the collaborative and collective state tendency among things, systems, or elements.

In the Asian region, Mahbubani [47] introduces "March to Modernity," where countries in Asia see that the market economy is pragmatic. Japan, China, South Korea, India, and Singapore are respective Asian countries' successes in implementing market mechanisms in their economies without abandoning religious values, traditions, and the State's role in politics and democracy. An example of Japan's performance in 1970-1990 was introducing Japan Incorporated with industrialization beyond the US and Europe. Thus, Japan Incorporated has the significant role of the State acted as a medium to synergize all forces in society, among other things private sector, parliament, research, and foreign representatives, with collaborative and productive long-term planning. The State then delegates all authority to the private sector to carry out corporate actions in national and global market mechanisms at the practical level.

In Indonesia, Salim [48] introduce the Pancasila Economy. And Budiman [49] emphasized the social element still needs the role of the State. Like western countries underline the part of the market, but the State's role remains side by side with the economy, which ensures the welfare of its people through social security for the whole community, based on three motives of the Pancasila Market Economy, namely: economic, social and moral motives. The Pancasila market economy approach extends to cooperatives or the family economy with the involvement of the Government's role. Intervention from the Government to produce an optimal balance between the market economy and the welfare of the people.

Conscious or not, many companies are adopting the competitive values of the competitive cooperative behavior of enterprises by forming strategic alliances for cooperation. The concept of coopetition usually refers to the relationship between companies that simultaneously compete and cooperate. In this concept, there is a combination of two complex logics, showing opposite interactions. The competitive paradigm with the goal that firms interact based on conflicting interests. In contrast, the collaborative paradigm states that companies interact based on interests.

Coopetition is a phenomenon of cooperation between organizations. As a relatively new research area, coopetition has its roots in cooperative strategies, both in a single dimension in the form of bilateral alliances and multilateral, among other things, networks and clusters. The coopetition-driven plan helps to develop a sustainable business. The development of the latest academic literature shows that the combination of cooperation and competition or "coopetition" is the choice of the business world over competition per se. Coopetition is a different strategic alternative due to changes in the new business environment by providing an alternative to choosing competitive and cooperative strategies [50]. The positive role of competition also emphasizes the importance of cooperation from different perspectives by arguing that "mutual trust, mutual commitment, cooperation, and exchange" are important factors that affect "the degree of relationship." The last decade has been marking by the dynamic growth of coopetition around the world. The coopetition-driven strategy helps to develop a sustainable business [51].

Coopetition may become the interpretation for one Indonesian competition law's purposes: to create a advantageous business environment through fairly business competition, thus securing equal business opportunities for MSMEs. However, the MSMEs are exempt from the Indonesian competition law.

\section{CROSSING PATH OF COMPETITION AND PARTNERSHIP}

In Indonesia, 99,99\% of businesses appertain as MSMEs [52]. They play an essential role in the Indonesian economy because able to expand employment and provide financial services widely to the community. In addition, SMEs are important in increasing people's income, even distribution and encouraging economic growth, and achieving national stability. Furthermore, MSMEs saved the Indonesian economy from the downturn due to the 1998 financial crisis. Those all make SMEs one of the core pillars of the national economy that must obtain the key opportunities, the broadest possible support, protection, and development, without neglecting large enterprises' role and SOEs. Even though MSMEs have shown their role in the national economy, they still encounter various internal and external challenges, such as production and processing, marketing, human resources, design and technology, capital, and the business climate. The government realizes and creates multiple policies to increase MSMEs' opportunities, capabilities, and protection, but still not optimum.

Coopetition might be an outlandish term. However, the definition of coopetition connotates with the partnership. Article 1 sub. 13 of Law N.20/2008 on MSMEs describes the partnership as "cooperation in business, directly and indirectly, based on mutual necessity, trust, strengthening, and benefit principles engaging MSMEs and Large Enterprises." Furthermore, as the implementation regulation of Law N.20/2008, 
article 119 of Government Regulation N.07/2021 on Facility, Protection, and Empowerment of Cooperatives and MSMEs assigns the Indonesian Competition Commission (ICC) to supervise the implementation of the partnership.

Article 104(1) GR N.7/2021 regulates that partnership between micro/small business and medium/large enterprises carried out with due observance of the principles of partnership and uphold sound business ethics. The principle of partnership includes the code of mutual need, trust, strength, and benefit. Article 119(3) GR N.7/2021 instructs ICC to regulate the supervision procedures, but not clear if the guidelines are from the perspective of MSMEs law only or the standpoint of competition law as ICC expertise. Quoad, article 119(1) GR N.7/2021only reveals that ICC performs supervision of the implementing agreement of partnership by the provisions of laws and regulations.

Furthermore, under article 122 of GR N.7/2021, the ICC has the power to investigate partnership cases and impose sanctions, including orders to revoke the business licenses of large/medium businesses that violate partnerships. Issues may occur from MSMEs harms by the ownership/or business control in the partnership relation with large corporation, micro or small enterprises harms by the ownership or business control in partnership with medium businesses; or individuals know concerning the conjecture violation of partnership implementation. But, again, the MSMEs law not giving clear guidance based on the case handling procedures perspective, the partnership aspect purely or with competition nuance.

One top note, a partnership is a form of agreement that must fulfill the principles of the contract beneath civil law. A partnership agreement is commonly in writing and contains rights and obligations for the parties, including dispute resolution. Since a partnership agreement is subject to civil law, the quarrel among parties may lead to civil disputes, for instance, in the event of a default by one of the parties. However, civil disputes are beyond the ICCs authority to examine and investigate.

Another issue on jurisdiction is almost every agreement has a choice of law for dispute resolution, whether through the court chooses or over alternative dispute resolution, such as mediation or arbitration. The principle of contact in Indonesia stands for those legitimate agreements that apply as laws for the parties. As an illustration, a partnership agreement chooses civil court as their choice of law for any dispute that may arise. Later, an issue on the misuse of business control in the partnership relation among micro and large business occur. Should the parties go to civil court only? May ICC intervene and take over the dispute, then convert it into an ICC case? Is it possible for parties in the agreement to sue ICC for interfering since the conflicts are not related to the competition?
Based on the concept of contract law, the contract acts as a law for both parties so that as far as possible, there is no intervention from the other party. The Pancasila market economy has an approach that extends to cooperatives or the family economy with the involvement of the Government's role to produce an optimal balance between the market economy and the welfare of the people. Furthermore, Indonesia adopts a positive law system, so there must be clear affirmation in the regulations regarding the authority of the ICC to intervene in partnership agreements. The intervention is limited to business competition as the expertise of the ICC, which cannot intervene in civil disputes.

The ICC has the best opportunity to regulate the supervision and case handling procedures properly. The ICC may construct those procedures under competition perspectives as its capability and authority. Article 35 of Law N.5/1999 states that one of the ICC's tasks is to evaluate agreements that may result in a monopoly or unfair business competition. Hence, the ICC has the authority to examine and assess partnership agreements.

Thus, in the supervision of the implementation of partnership, the ICC may oversee the agreement to implement these principles and supervisors related to potential violations of business competition, such as creating a barrier to entry or abuse of dominance, for instance, in a tying-in agreement or exclusive dealing. Furthermore, suppose any violation occurs from implementing the principles in the partnership agreement, the ICC may enforce the law against abuse of bargaining position focuses on protecting MSMEs over the domination of large businesses as business partners in implementing partnership relations. The same action applies if the misuse of ownership/or business control in the partnership relation arises.

\section{CONCLUSION}

Based on the economic system and the constitution, Indonesia has shown a strong acknowledgment that the economy of cooperation and kinship is an inherent ideology. Competition is not outlandish, but from Pancasila as the perspective of the Indonesian nation and the economic system is the Pancasila Economy which focuses on the principle of togetherness, Indonesia must build its paradigm in competition and partnership, which stands on a balance between the forces of competition and cooperation. Coopetition emerged as a mutual interest that puts forward mutualism, brotherhood, and synergy without forgetting efficiency to face globalization.

Without the concept of coopetition as a middle ground, competition and partnership will always be at the crossroads and never meet. ICC has the opportunity given by the regulations to prepare two guidelines, supervising partnership and case handling procedures. Through the 
caring partnership, ICC can introduce the concept of coopetition as a combination of partnership and business competition. Through case handling schemes, the ICC can distinct its jurisdiction and confirm that the ICC can intervene in partnership agreements as a manifestation of the State's political economy in favor of MSMEs.

\section{REFERENCES}

[1] J.-E. Lane and S. Ersson, Comparative Political Economy: A Development Approach, London, Washington: Pinter, 1997, p. 129.

[2] Law N.5/1999, General Elucidation.

[3] R. Iriana and F. Sjöholm, "Indonesia's Economic Crisis: Contagion and Fundamentals," The Developing Economies, Vols. XL-2, pp. 135-151, June 2002.

[4] R. S. Khemani, " Framework for the Design and Implementation of Competition Law and Policy," World Bank \& OECD, Washington DC \& Paris.

[5] P. A. Samuelson and W. D. Nordhaus, "Economics," McGraw Hill, Boston, 2009.

[6] B. Song, "Competition Policy in a Transitional Economy: the Case of China," Stanford Journal of International Law, vol. 31, no. 387, pp. 407-418, 1995.

[7] People's Consultative Assembly Resolution N.XVI/MPR/1998 on Economic Policy in the Framework of Economic Democracy.

[8] J. H. Burns, "Happiness and Utility: Jeremy Bentham's Equation," Utilitas, vol. 17, no. 1, March 2005.

[9] D. Benassi, "ResearchGate.net," Sociologica DOI:10.2383/33647, 2010. [Online]. Available: Father of the welfare state? Beveridge and the emergence of the welfare state. [Accessed October 2021].

[10] A. Smith, An Inquiry into the Nature and Causes of the Wealth of Nation, S. M. Soares, Ed., MetaLibri Digital Library, 2007, p. 367.

[11] J. Giles Burges, The Economic of Regulation and Antitrust, New York: Harper Collins College, 1995, pp. 5-6.

[12] A. W. Katz, Foundations of the Economic Approach to Law, Oxford University Press, 1998, p. 39.

[13] K. Marx, "Marxists Internet Archive Library," [Online]. Available: https://www.marxists.org/archive/marx/works/dow nload/pdf/Capital-Volume-I.pdf.

[Accessed October 2021].

[14] A. Brewer, Kajian Kritis Das Kapital Karl Marx, Jakarta: Teplok Press, 2000.
[15] Y. Kunio, The Rise of Ersatz Capitalism in South East Asia, Singapore: Oxford University Press, 1998.

[16] F. List, "The National System of Political Economy," Longmans, Green, and Co., London, 1909.

[17] M. K. Sari, "Crony Capitalism and Post-Crisis Economy In Indonesia And The Philippines," Jurnal Kajian Wilayah, vol. 7, no. 1, 2016.

[18] Mubyarto, Membangun Sistem Ekonomi, Yogyakarta: BPFE, 2000, p. 10.

[19] H. A. Kadir, "Komparasi Munculnya Liberalisme Ekonomi di Indonesia dan Burm," Lembaran Sejarah, vol. 13, no. 2, October 2017.

[20] N. N. Sirait, "Indonesia dalam Menghadapi Persaingan Internasional," in Rapat Terbuka Universitas Sumatera Utara Pengukuhan Jabatan Guru Besar Tetap dalam Bidang Ilmu Hukum Internasional pada Fakultas Hukum, Medan, 2006.

[21] M. Fuady, Sosiologi Hukum Kontemporer: Interaksi Hukum Kekuasaan dan Masyarakat, Jakarta: Kencana, 2011, p. 61.

[22] A. Schwarz, A Nation in Waiting, Indonesia in the 1990s, Westview Press, 1994.

[23] H. Hill, The Indonesian Economy, Melbourne,: Cambridge University Press,, 2000.

[24] J. S. Wilson, "Why Foreign Aid Fails: Lessons from Indonesia's Economic Collapse," Law and Policy in International Business, vol. 33, no. 1, 2001.

[25] U. Mustafa and D. Bulent, "The Determinants of Economic Fragility: Case of the Fragile Five Countries," https://mpra.ub.unimuenchen.de/68734/1/MPRA_paper_68734.pdf, 2015.

[26] Mubyarto, "Peran Ilmu Ekonomi Dalam Pemberdayaan Ekonomi Rakyat," Jurnal Ekonomi dan Bisnis Indonesia, vol. 17, no. 3, pp. $233-242$, 2002.

[27] Hastangka, "Filsafat Ekonomi Pancasila Mubyarto," Jurnal Filsafat, vol. 22, no. 1, 2012.

[28] F. Bawazier, "Sistem Ekonomi Pancasila: Memaknai Pasal 33 UUD 1945," Jurnal Keamanan Nasional,, vol. III, no. 2, 2017.

[29] S. Atmoredjo, Ideologi Hukum Indonesia, Kajian tentang Pancasila dalam Perspektif Ilmu Hukum dan Dasar Negara Indonesia, Yogyakarta: Lingkar Media Yogyakarta, 2016.

[30] J. J. Flyin, Antitrust Policy and The Concept of a Competitive Process, New York: New York Law School Law Review, 1990.

[31] R. Bork and W. S. Bowman, "The Crisis in Antitrust," Columbia Law Review, vol. 65, 1965. 
[32] P. Asch, Industrial Organization and Antitrust Policy, Canada: John Willey \& Sons, Inc., 1983.

[33] F. Scherer, Competition Policies for an Integrated World Economy, Washington DC: The Brookings Institution, 1994.

[34] T. O. f. E. C.-o. a. Development, Glossary of Industrial Organization Economics and Competition Law, English Version, Paris: OECD, 1996.

[35] H. C. Black, Black's Law Dictionary, Defenition of the Terms and Phrases of American and English Jurisprudence, Ancient and Modern, St. Paul, Minnesota: West Publishing, Co., 1990.

[36] J. Stiglitz, The Roaring Nineties, London: Penguin Books, 2003.

[37] A.-P. E. Cooperation, "Asia-Pasific Economic Cooperation," APEC Secretariat, 17 November 2004. [Online]. Available: https://www.apec.org/Meeting-Papers/AnnualMinisterial-Meetings/2004/ 2004_amm. [Accessed 1 October 2021].

[38] e. Philip Kotler, The Marketing of Nations, A Strategic Approach to Building National Wealth, New York: The Free Press, 1997.

[39] F. T. Commission, "Guide to Antitrust Laws," [Online]. Available: https://www.ftc.gov/tipsadvice/competition-guidance/guide-antitrust-laws. [Accessed 1 October 2021].

[40] P. Lowe, "Preserving and Promoting Competition: A European Response," Summer 2006. [Online]. Available:

https://ec.europa.eu/competition/publications/cpn/2 006_2_1.pdf. [Accessed 1 October 2021].

[41] R. B. Setianingrum and M. Hawin, "Harmonization of Competition Law: Research on the Transplantability of EU's Law into ASEAN," Yuridika, vol. 35, no. 3, pp. 613-634, September 2020.

[42] W. Youming, "realinstitutoelcano.org," 10 September 2010. [Online]. Available: http://www.realinstitutoelcano.org/wps/wcm/conne ct/699e2f8043e6b5808406b78f038e2cc0/ARI1332010_WangYouming_EU_Global_Governance_C hina_Armonious_World.pdf?MOD=AJPERES\&C ACHEID=699e2f8043e6b5808406b78f038e 2cc0. [Accessed 1 October 2021].
[43] W. Youming, "realistitutoelcano.org," 10 September 2010. [Online]. Available: http://www.realinstitutoelcano.org/wps/wcm/conne ct/699e2f8043e6b5808406b78f038e2cc0/ARI1332010_WangYYouming_EU_Global_Governance_C hina_Armonious_World.pdf?MOD=AJPERES\&C $\mathrm{ACHEID}=699 \mathrm{e} 2 \mathrm{f} 8043 \mathrm{e} 6 \mathrm{~b} 5808406 \mathrm{~b} 78 \mathrm{f} 038 \mathrm{e} 2 \mathrm{cc} 0$. [Accessed 1 October 2021].

[44] A. M. Brandenburger and B. J. Nalebuff, Coopetition, New York: Doubleday, 1996.

[45] K. Mahbubani, The New Asian Hemisphere: The Irresistible Shift of Global Power to The East, New York: PublicAffairs, 2008.

[46] D. Rahardjo, "Ekonomi Pancasila dalam Tinjauan Filsafat Ilmu," Pusat Studi Ekonomi Kerakyatan Universitas Gadjah Mada, 9 January 2021. [Online]. Available: https://ekonomikerakyatan.ugm.ac.id/publikasi/eko nomi-pancasila-dalam-tinjauan-filsafat-ilmu/. [Accessed 1 October 2021].

[47] A. Budiman, Sistem Perekonomian Pancasila dan Ideologi Ilmu Sosial di Indonesia, Jakarta: Gramedia Pustaka Utama, 1990.

[48] K. Blind, B. Ebersberger and A. Lorenz, "Coopetition, Cooperation and Competition as Determinants of Companies' Appropriation Strategies," 13 September 2013. [Online]. Available: Available at SSRN: https://ssrn.com/abstract=2145165 or http://dx.doi.org/10.2139/ssrn.. [Accessed 1 October 2021].

[49] K. Rose, "Why You Should Cooperate With the Competition," Success Magazine, 21 December 2017. [Online]. Available: https://www.success.com/why-you-shouldcooperate-with-the-competition/. [Accessed 1 October 2021].

[50] S. Indonesia, "Statistical Yearbook of Indonesia 2021," 26 February 2021. [Online]. Available: https://www.bps.go.id/publication/download.html? nrbvfeve=OTM4MzE2NTc0Yzc4NzcyZjI3ZTliN Dc3\&xzmn=aHR0cHM6Ly93d3cuYnBzLmdvLml kL3B1YmxpY2F0aW9uLzIwMjEvMDIvMjYvOT M4MzE2NTc0Yzc4NzcyZjI3ZTliNDc3L3N0YX Rpc3Rpay1pbmRvbmVzaWEtMjAyMS5odG1s\&t woadfnoarfeauf=MjAyMSOxMC0. [Accessed 1 October 2021]. 